\title{
Some factors controlling food intake by zinc-deficient rats
}

\author{
By J. K. CHESTERS AND MARIE WILL \\ Rowett Research Institute, Bucksburn, Aberdeen, AB2 $9 S B$
}

$$
\text { (Received } 23 \text { February } 1973 \text { - Accepted } 31 \text { May 1973) }
$$

1. Male hooded Lister rats given a diet containing $40 \mathrm{mg}$ zinc/kg were described as $Z_{n}$ adequate. Other rats were subsequently given diets containing less than $\mathrm{Img} \mathrm{Zn} / \mathrm{kg}$. After a period of approximately $5 \mathrm{~d}$ these animals ceased to grow and were described as $\mathrm{Zn}$-deficient.

2. Zn-deficient rats offered $a d l i b$. a $\mathrm{Zn}$-deficient diet containing $200 \mathrm{~g} \mathrm{egg}$ albumen $/ \mathrm{kg}$ ate only $55 \%$ of the weight eaten by $\mathrm{Zn}$-adequate rats given a similar diet supplemented with $\mathrm{Zn}_{\mathrm{n}}$. The intake of the deficient rats increased when the metabolizable energy content of the diet was decreased and also when the environmental temperature was lowered.

3. Zn-deficient rats offered $\mathrm{Zn}$-deficient diets containing $200 \mathrm{~g} \mathrm{cgg}$ albumen $/ \mathrm{kg}$ showed a high day-to-day variability of intake. When the albumen content was raised to $400 \mathrm{~g} / \mathrm{kg}$, neither the mean food intake of the rats nor the variability of food intake changed, but with diets containing only $50 \mathrm{~g}$ albumen $/ \mathrm{kg}$ the quantity eaten increased and the variability of food intake decreased. Results obtained when the low-protein diet was supplemented with essential and non-essential amino acids indicated that increased variability of intake was associated with the essential amino acid content of the diet. The effect on variability of intake was greatest when the supplements contained methionine, phenylalanine, threonine and tryptophan; addition of this group of amino acids to a $\mathrm{Zn}$-supplemented, low-protein diet produced the largest increase in the growth rate of $\mathrm{Zn}$-adequate rats.

4. When the food intake of the rats was examined for periods of $2 \mathrm{~h}$ throughout the day, the $\mathrm{Zn}$-deficient rats were found to eat on fewer occasions than the control rats. However, in those periods when the $\mathrm{Zn}$-deficient rats did eat, the quantitics eaten in $2 \mathrm{~h}$ showed the same distribution of weights as did those for the $\mathrm{Zn}$-adequate rats.

5. There were significant relationships between food intake and plasma $Z n$ concentration; the most significant was the negative correlation between food intake in $24 \mathrm{~h}$ and plasma $\mathrm{Zn}$ concentration at the end of the $24 \mathrm{~h}$ period.

6. Zn deficiency resulted in a failure of growth in the young rat and therefore in a reduction in its rate of energy expenditure but did not appear to cause directly a loss of appetite. It is suggested that cyclical patterns of food intake associated with $\mathrm{Zn}$ deficiency in young rats resulted from the slow but effective control of food intake by the energy balance of the animals.

Rats made zinc-deficient by consumption of diets low in $\mathrm{Zn}$ suffer a marked reduction both in growth rate and food intake (Williams \& Mills, I970) and the latter is accompanied by an increase in the day-to-day variability of intake (Chesters $\&$ Quarterman, I970; Pallauf \& Kirchgessner, 1971; Griffith \& Alexander, I972). Force-feeding experiments have shown that the poor rate of growth of $\mathrm{Zn}$-deficient rats is not due to a low food consumption but is caused by a failure of an unknown process which requires $\mathrm{Zn}$ and is essential for growth (Chesters \& Quarterman, 1970).

The present study attempts to define some of the factors governing both the mean daily food intake of $\mathrm{Zn}$-deficient rats and the wide day-to-day fluctuations, or cycles, of intake. 
Table I. Composition of experimental diets $(\mathrm{g} / \mathrm{kg})$

(The diets were based on those described by Williams \& Mills (1970) and only those constituents whose concentrations were altered experimentally are listed below. Most diets were used both with and without zinc supplementation. $\mathrm{Zn}$-supplemented diets contained $\mathrm{ZnSO}_{4}$ at a final concentration of $40 \mathrm{mg} \mathrm{Zn} / \mathrm{kg}, \mathrm{Zn}$-deficient diets contained $0.4-0.9 \mathrm{mg}$ $\mathrm{Zn} / \mathrm{kg})$

\begin{tabular}{|c|c|c|c|c|c|}
\hline Diet & Egg albumen & Amino acids & & Cellulose & Sucrose \\
\hline Standard & 200 & 一 & & 一 & 660 \\
\hline Cellulose & 200 & - & & 300 & 360 \\
\hline High-protein (HP) & 400 & - & & - & 460 \\
\hline Low-protein (LP) & 50 & - & & - & $8 \mathrm{IO}$ \\
\hline $\mathrm{LP}+$ Glu & 50 & L-glutamic acid & 250 & - & 560 \\
\hline LP + Cys + Met & $5 \circ$ & $\begin{array}{l}\text { L-cysteine } \\
\text { L-methionine }\end{array}$ & $\begin{array}{l}2 \cdot 8 \\
6 \cdot 0\end{array}$ & - & 801 \\
\hline $\mathbf{L P}+\mathbf{N E}$ & 50 & Non-essential amino acids* & 73 & - & 737 \\
\hline $\mathrm{LP}+\mathrm{E}$ & 50 & Essential amino acidst & 79 & - & $73 I$ \\
\hline A & 50 & $\begin{array}{l}\text { L-isoleucine } \\
\text { L-leucine } \\
\text { L-valine }\end{array}$ & $\begin{array}{r}8 \cdot 5 \\
13 \cdot 0 \\
10.5\end{array}$ & - & 778 \\
\hline $\mathbf{B}$ & 50 & $\begin{array}{l}\text { L-arginine } \\
\text { L-histidine } \\
\text { L-lysine }\end{array}$ & $\begin{array}{r}8 \cdot 8 \\
3 \cdot 8 \\
10 \cdot 4\end{array}$ & - & 787 \\
\hline $\mathrm{C}$ & 50 & $\begin{array}{l}\text { L-methionine } \\
\text { L-phenylalanine } \\
\text { L-threonine } \\
\text { L-tryptophan }\end{array}$ & $\begin{array}{l}6 \cdot 0 \\
8 \cdot 8 \\
7 \cdot 2 \\
2 \cdot 0\end{array}$ & - & 786 \\
\hline
\end{tabular}

NE, non-essential amino acids; $E$, essential amino acids.

* L-alanine $6 \cdot 8$, L-aspartic acid I $7 \cdot 0$, L-cysteine $2 \cdot 8$, L-glutamic acid $23 \cdot 0$, L-glycine $5 \cdot 5$, L-serine $9 \cdot 7$ and L-tyrosine $6 \cdot 2$.

$+\mathrm{L}$-arginine $8 \cdot 8$, L-histidine $3.8, \mathrm{~L}$-isoleucine 8.5 , L-leucine $13 \cdot 0, \mathrm{~L}$-lysine $10.4, \mathrm{~L}$-methionine $6 \cdot 0$, L-phenylalanine $8 \cdot 8$, L-threonine $7 \cdot 2, \mathrm{~L}$-tryptophan $2 \cdot 0$ and $\mathrm{L}$-valine $10 \cdot 5$.

\section{METHODS}

\section{Expt I. Effects of diet composition on food intake}

Animals. A group of eight male hooded Lister rats was used for each of the experimental treatments. The rats were reared and kept under 'barrier-maintained' conditions and were housed singly in Perspex-and-glass cages described by Quarterman, Williams \& Humphries (1970). The rats were weaned on the standard $\mathrm{Zn}$ supplemented diet and allowed to grow to $80 \mathrm{~g}$ (approximately $3 \circ \mathrm{d}$ of age) before being used for experiment.

Experimental design. The semi-synthetic diet described by Williams \& Mills (1970) was used as the standard diet for all experiments. The experimental modifications to this diet are shown in Table $\mathrm{r}$. The diet containing cellulose was designed to have a lower metabolizable energy content than the standard diet. Diet LP+Glu had the same nitrogen content as the standard diet but contained the low protein concentration. The supplementary amino acids of diets $\mathrm{LP}+\mathrm{NE}, \mathrm{LP}+\mathrm{E}, \mathrm{A}, \mathrm{B}$ and $\mathrm{C}$ increased the dietary concentrations of individual amino acids to those present in the standard diet as determined by amino acid analysis of the egg albumen used for diet preparation. The value for tryptophan was assumed to be $14 \mathrm{~g} / \mathrm{kg}$ egg albumen. 
The cellulose used for diets was Whatman $\mathrm{CC}_{4} \mathrm{I}$ microgranular cellulose powder (Koch-Light Laboratories, Colnbrook, Bucks.). Amino acids were supplied by Cambrian Chemicals Ltd, Croydon, Surrey.

Each diet was offered ad lib. to a group of eight rats whose body-weights and food intakes were recorded daily. The effects of the diets on the growth and food intake of rats were analysed for periods of at least $\mathrm{I}_{4}$ consecutive $\mathrm{d}$. Sufficient time was allowed after a change of diet to permit the new pattern of growth and food intake to be established before starting the period of analysis.

Calculation of food intake and the day-to-day variability of food intake. The results were analysed by methods similar to those described by Chesters \& Quarterman (1970). When comparing food intakes, it was essential that the comparisons were made between rats of a standard weight, and rats weighing $110 \mathrm{~g}$ (occasionally $90 \mathrm{~g}$ ) were used. For growing rats, regressions of body-weight and food intake against time were calculated for each rat and, from these, a calculated value for the food intake of the rat at the standard weight was obtained. The standard deviation of food intake from its regression on time was the basis of the estimate of the day-to-day variation in food intake. These values for each rat were used to calculate a mean food intake at the standard weight and a mean variability of intake for the group together with standard errors of the group means. In one experiment which involved a comparison of the growth rates of rats on different diets, the growth rate of each rat was estimated from the slope of the regression of body-weight on time and means with their standard errors were calculated for the groups.

When the diets prevented growth, the rats were selected so that the range of their weights in the experimental period bracketed the standard weight. Mean body-weight and mean food intake were calculated for each rat for the period and the day-to-day variability of intake was estimated for each rat by regression analysis of its food intake on time. Additional regressions were then calculated relating both the mean food intake and its variability to the mean body-weights of the rats of a group in the experimental period. From these regressions an estimate was obtained of the mean food intake and its variability at the standard weight.

\section{Expt 2. Pattern of food intake during successive $2 h$ periods}

To determine the pattern of food intake of rats during successive $2 \mathrm{~h}$ periods over $24 \mathrm{~h}$, a Perspex-and-glass cage of the type described by Quarterman et al. (1970) was modified as follows. The Perspex food disc was increased to a diameter of $135 \mathrm{~mm}$ and the feeding groove was enlarged and subdivided radially into twelve equal segments capable of holding $2 \cdot 5-3 \mathrm{~g}$ of the diet. The motor attached to the disc was activated by a timer and microswitch system which ensured that the disc rotated through one segment at the end of each $2 \mathrm{~h}$ period and the rat therefore had access to a fresh batch of 2 or $2.5 \mathrm{~g}$ of diet every $2 \mathrm{~h}$. This quantity was sufficient to provide the rat with an amount of food in excess of its voluntary consumption in $2 \mathrm{~h}$ and the rats were therefore considered to have had $a d l i b$. access to the diet. The diet was weighed into each individual segment and at the end of the $24 \mathrm{~h}$ period the amount of diet eaten from each segment was recorded to the nearest $0 . \mathrm{I} \mathrm{g}$. These food intakes 
were then allocated to a series of six weight ranges and the proportion of the total number of intakes in each weight range was calculated.

With $\mathrm{Zn}$-supplemented diets allowing growth, the intakes of three rats were investigated for a period of $5-7 \mathrm{~d}$ centred about the time at which the weight of the rats reached I Iog. With $\mathrm{Zn}$-deficient rats which were not growing, three rats were selected so that the mean body-weights of the rats were as near as possible to I Io $\mathrm{g}$.

\section{Expt 3. Relationship between plasma $Z n$ concentration and food intake of $Z$ n-deficient rats}

A group of eight male rats was fed and housed as described in Expt I. The rats were given the standard $\mathrm{Zn}$-deficient diet and attained body-weights averaging approximately I I $\mathrm{g}$ before growth ceased after $5 \mathrm{~d}$. Duplicate blood samples were taken from the tail vein at 09.30 hours each day in heparinized micro-haematocrit tubes (Gelman-Hawksley Ltd, Lancing, Sussex), the tubes were sealed at one end and centrifuged. Samples of plasma $(0.5 \mu 1)$ were taken directly from the tubes with a micro-syringe and their $\mathrm{Zn}$ content was estimated by atomic absorption spectrophotometry with the carbon rod attachment of a Techtron AA-5 atomic absorption spectrophotometer (Varian Associates Ltd, Walton-on-Thames, Surrey). With a 'West'-type rod, plasma $\mathrm{Zn}$ concentrations estimated were similar over a wide range to results obtained with the conventional flame method of atomic absorption spectrophotometry. Samples of plasma from the tail vein of a rat were also found to have the same $\mathrm{Zn}$ concentration as plasma taken from the same rat by heart puncture.

Both food intake and plasma $\mathrm{Zn}$ concentration varied in a cyclical manner with time, and it was found that there was more than one significant correlation between plasma $\mathrm{Zn}$ concentration and food intake depending on the relative times at which the two variables were estimated. It was necessary to test whether the closeness of association of one of these correlations was significantly greater than those of the rest. The method of Hotelling (1940) was used for this purpose; the rats were considered individually and then the results were pooled to assess the final correlations and their significance.

\section{RESULTS}

\section{Expt I. Effects of dietary composition on food intake}

Control of average daily food intake of $Z n$-deficient rats. Table 2 gives values for the food intake of rats on the standard $\mathrm{Zn}$-supplemented and $\mathrm{Zn}$-deficient diets. Results showed that there was a fall in mean food intake and an increase in its variability which is characteristic of $\mathrm{Zn}$ deficiency (Chesters \& Quarterman, 1970). Reduction of the metabolizable energy content of the $\mathrm{Zn}$-deficient diet resulted in a significant increase in the mean intake compared with that of rats offered the standard $\mathrm{Zn}$-deficient diet; the increase in variability of food intake was not, however, statistically significant. When the rats were offered the standard $\mathrm{Zn}$-deficient diet but housed at a lower ambient temperature, thus increasing their energy requirements, food intake nearly doubled and there was no change in the variability of intake.

Effect of the albumen content of the diet. Rats offered the Zn-supplemented, low- 
Table 2. Expt I. Effects of varying dietary zinc content, the addition of cellulose to the diet and cold exposure on the food intake of the groups of eight male rats weighing $\mathrm{I} \mathrm{r} g$

\begin{tabular}{|c|c|c|}
\hline \multicolumn{2}{|c|}{ Dietary supplement } & \multirow[b]{2}{*}{$\begin{array}{c}\text { Environmental } \\
\text { temperature } \\
\left({ }^{\circ} \mathrm{C}\right)\end{array}$} \\
\hline $\begin{array}{c}\mathrm{Zn} \\
(\mathrm{mg} / \mathrm{kg})\end{array}$ & $\begin{array}{c}\text { Cellulose } \\
(\mathrm{g} / \mathrm{kg})\end{array}$ & \\
\hline 40 & 0 & 22 \\
\hline 0.9 & 0 & 22 \\
\hline 0.8 & 300 & 22 \\
\hline 0.8 & 0 & 10 \\
\hline
\end{tabular}

\begin{tabular}{|c|c|}
\hline \multicolumn{2}{|c|}{$\begin{array}{l}\text { Food intake } \\
\qquad(\mathrm{g} / \mathrm{d})\end{array}$} \\
\hline Mean & $\mathrm{SE}$ \\
\hline $12 \cdot 2$ & $0.2^{2}$ \\
\hline $6 \cdot 8$ & $0.3^{1}$ \\
\hline $8 \cdot 4$ & $0.5^{\circ}$ \\
\hline 130 & $0.3^{\circ}$ \\
\hline
\end{tabular}

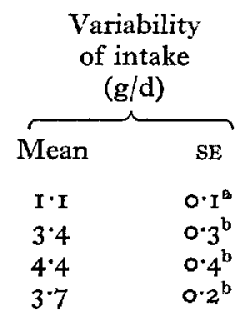

Within a column values, without common superscripts are significantly different $(P<0.05)$

Table 3. Expt I. Effects of varying zinc and egg albumen contents of the diet on the food intake of groups of eight male rats weighing $90 \mathrm{~g}$

$\begin{array}{cr}\begin{array}{c}\mathrm{Zn} \\ (\mathrm{mg} / \mathrm{kg})\end{array} & \begin{array}{c}\text { Albumen } \\ (\mathrm{g} / \mathrm{kg})\end{array} \\ 40 & 200 \\ 40 & 50 \\ 0.8 & 200 \\ 0.6 & 50\end{array}$

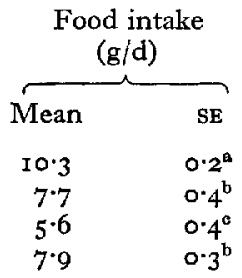

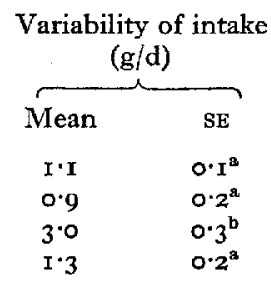

Within a column values, without common superscripts are significantly different $(P<0.05)$.

Table 4 . Expt $\mathrm{I}$. Effects of varying amino acid content of the diet on the food intake of groups of eight zinc-deficient male rats weighing $\mathrm{I} I \mathrm{~g}$

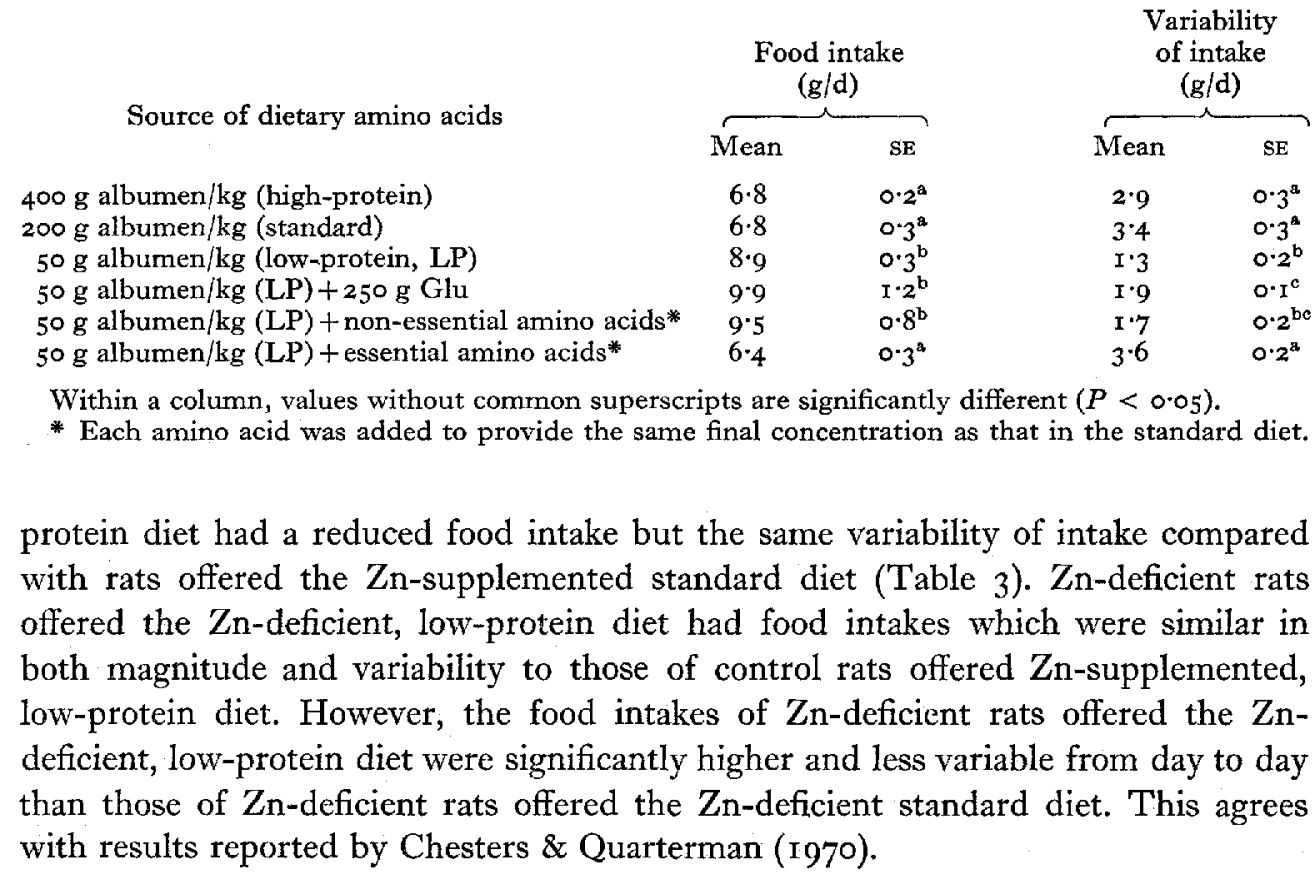


Table 5. Expt I. Effects of amino acid supplementation of low-protein, zinc-deficient diets on the food intake of groups of eight male rats weighing I I $g$

\begin{tabular}{|c|c|c|c|c|}
\hline \multirow[b]{2}{*}{ Source of dietary amino acids } & \multicolumn{2}{|c|}{$\begin{array}{l}\text { Food intake } \\
\qquad(\mathrm{g} / \mathrm{d})\end{array}$} & \multicolumn{2}{|c|}{$\begin{array}{c}\text { Variability } \\
\text { of intake } \\
(\mathrm{g} / \mathrm{d})\end{array}$} \\
\hline & Mean & $\mathrm{SE}$ & Mean & $\mathrm{SE}$ \\
\hline $5 \circ \mathrm{g}$ albumen $/ \mathrm{kg}$ (low-protein, LP) & $8 \cdot 2$ & $0 \cdot 3^{a}$ & I'I & $0 \cdot 1^{a}$ \\
\hline $5^{\circ} \mathrm{g}$ albumen $/ \mathrm{kg}(\mathrm{LP})+\mathrm{ile}$, leu, val $(\mathrm{A})^{*}$ & $6 \cdot \mathrm{I}$ & $0.7^{\mathrm{bec}}$ & $\mathrm{r} \cdot 3$ & 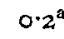 \\
\hline $5 \circ \mathrm{g}$ albumen $/ \mathrm{kg}(\mathrm{LP})+\arg$, his, lys $(\mathrm{B})^{*}$ & $7 \cdot \mathrm{I}$ & $0.4^{b}$ & 0.9 & $0 \cdot \mathrm{r}^{\mathrm{a}}$ \\
\hline $5^{\circ} \mathrm{g}$ albumen $/ \mathrm{kg}(\mathrm{LP})+$ met, phe, thr, try $(\mathrm{C})^{*}$ & $6 \cdot 5$ & $0.9^{b c}$ & $2 \cdot 3$ & 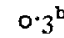 \\
\hline \multicolumn{5}{|l|}{ Mixed diets $(\mathrm{I}: \mathrm{I}, \mathrm{w} / \mathrm{W})$ : } \\
\hline$A+B$ & $5 \cdot 6$ & $0.8^{\mathrm{be}}$ & i.o & $0 \cdot 1^{\mathrm{a}}$ \\
\hline $\mathrm{B}+\mathrm{C}$ & 5.3 & $0.5^{\mathrm{c}}$ & $\mathrm{r} \cdot 4$ & $0.3^{\mathrm{a}}$ \\
\hline$A+C$ & $6 \cdot x$ & $0.3^{\mathrm{bc}}$ & $2 \cdot 8$ & \\
\hline
\end{tabular}

Within a column, values without common superscripts are significantiy different $(P<0.05)$.

* Each amino acid was added to provide the same final concentration as that in the standard diet.

Table 6. Expt r. Effect of amino acid supplementation of low-protein, zinc-adequate diets on the growth rate and food intake of male rats weighing $90 \mathrm{~g}$

Source of dietary amino acids

$5 \circ \mathrm{g}$ albumen $/ \mathrm{kg}$ (low-protein, LP)

$5 \circ \mathrm{g}$ albumen $/ \mathrm{kg}(\mathrm{LP})+\mathrm{ile}$, leu, val $(\mathrm{A}) *$

$50 \mathrm{~g}$ albumen/kg (LP) + arg, his, lys (B)*

$50 \mathrm{~g}$ albumen/kg (L.P) + met, phe, thr, try (C)*

Mixed diets $(\mathrm{I}: \mathrm{I}, \mathrm{w} / \mathrm{w})$ :

$A+B$

$\mathrm{B}+\mathrm{C}$

$\mathrm{A}+\mathrm{C}$
Food

intake

$(\mathrm{g} / \mathrm{d})$

$\begin{array}{cc}\text { Nean } & \text { SE } \\ 6.44 & 0.11^{a} \\ 4.56 & 0.12^{b} \\ 5.27 & 0.21^{b} \\ 6.50 & 0.12^{a} \\ 4.83 & 0.09^{b} \\ 4.60 & 0.11^{b} \\ 6.58 & 0.30^{a}\end{array}$

Variability of intake $(\mathrm{g} / \mathrm{d})$

\begin{tabular}{ll} 
Mean & \multicolumn{1}{c}{ SE } \\
0.90 & $0.12^{\mathrm{ab}}$ \\
0.76 & $0.04^{\mathrm{a}}$ \\
$\mathrm{r} .0 \mathrm{I}$ & $0.07^{\mathrm{b}}$ \\
$\mathrm{x} 59$ & $0.12^{\circ}$ \\
0.92 & $0.08^{\mathrm{ab}}$ \\
0.66 & $0.06^{\mathrm{a}}$ \\
$\mathrm{I} .59$ & $0.3 \mathrm{I}^{\mathrm{bc}}$
\end{tabular}

Growth rate $(\mathrm{g} / \mathrm{d})$

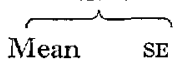

$0.03 \quad 0.07^{\mathrm{a}}$ $0.31 \quad 0.04^{b}$ $0.320 .04^{b}$ $1.02 \quad 0.04^{\mathrm{c}}$

$0.31 \quad 0.04^{b}$ $0.51 \quad 0.06^{\mathrm{d}}$ $\mathrm{I} \cdot 3 \mathrm{I} \quad 0.10^{\mathrm{e}}$

Within a column, values without common superscripts are significantly different $(P<0.05)$.

* Each amino acid was added to provide the same final concentration as that in the standard diet.

The results of further studies with $\mathrm{Zn}$-deficient rats in which rIog was the standard weight of rats are shown in Table 4 . Increasing the albumen content of the diet twofold did not significantly change either food intake or its variability compared with that of rats offered the standard, Zn-deficient diet. Low albumen content was again associated with an increase in food intake and the variability of food intake was lower.

Effects on food intake of supplementation with groups of essential amino acids. When the low-protein, Zn-deficient diet was supplemented with glutamic acid (diet LP + Glu) so that its nitrogen content was the same as that of the standard diet, both the food intake of $\mathrm{Zn}$-deficient rats and the variability of intake were increased. The latter was, however, significantly lower than that of the $\mathrm{Zn}$-deficient rats offered the standard $\mathrm{Zn}$-deficient diet (Table 4). The pattern of intake of $\mathrm{Zn}$-deficient rats offered diet $\mathrm{LP}+\mathrm{NE}$ was similar to that found with the diet $\mathrm{LP}+\mathrm{Glu}$. However, when the rats were offered $\mathrm{Zn}$-deficient diet $\mathrm{LP}+\mathrm{E}$, food intake decreased and was not signi- 
ficantly different either in quantity or variability from that of $\mathrm{Zn}$-deficient rats given the standard $\mathrm{Zn}$-deficient diet.

The food intakes of $\mathrm{Zn}$-deficient rats offered $\mathrm{Zn}$-deficient, low-protein diets supplemented with groups of amino acids (diets A, B and C) are shown in Table 5. In each instance the addition of the essential amino acids reduced food intake below that on the unsupplemented low-protein diet. However the variability of intake was not significantly affected by supplementation with the amino acids of diets $\mathrm{A}$ and $\mathrm{B}$. The amino acids of diet $\mathrm{C}$ significantly increased the variability of intake.

The $\mathrm{Zn}$-deficient diets $\mathrm{A}, \mathrm{B}$ and $\mathrm{C}$ were then mixed in pairs with equal proportions of each of the pair to produce three diets containing concentrations of the supplemented amino acids equal to those in diets containing $125 \mathrm{~g}$ albumen $/ \mathrm{kg}$. Even with this reduction in concentration of individual amino acids, there was an increase in the variability of intake with $\operatorname{diet} A+C$ whereas with diets $A+B$ and $B+C$ the amounts of group $\mathrm{A}$ and group $\mathrm{C}$ amino acids respectively were not sufficient to increase significantly the variability of intake. This suggests a synergistic effect between $\mathrm{A}$ and $\mathrm{C}$ groups of amino acids on the variability of intake found with diet $\mathrm{A}+\mathrm{C}$.

Table 6 gives the results of an experiment conducted with control rats offered $\mathrm{Zn}$ supplemented diets. Those offered the low-protein diet failed to grow, but when this diet was supplemented with any one of the three groups of essential amino acids there was a slow increase in body-weight. The amino acids of group $\mathrm{C}$ were more effective in stimulating growth than those of the other two groups. With mixtures of $\operatorname{diets} \mathrm{A}, \mathrm{B}$ and $\mathrm{C}$ in equal proportions, $\operatorname{diet} \mathrm{A}+\mathrm{C}$ produced the greatest stimulation of growth.

Effect of sulphur-containing amino acids on variability of intake. Hsu \& Anthony (1971) suggested a specific defect in the metabolism of sulphur-containing amino acids in $\mathrm{Zn}$-deficient rats. As methionine was among the group of amino acids which increased the variability of intake of $\mathrm{Zn}$-deficient rats, a $\mathrm{Zn}$-deficient, low-protein diet was supplemented with cysteine and methionine to final concentrations equivalent to those in the diet containing $200 \mathrm{~g}$ albumen $/ \mathrm{kg}$. Deficient rats given this diet ad lib. had the same mean food intake and day-to-day variation of intake as rats given the unsupplemented low-protein diet.

\section{Expt 2. Pattern of food intake during successive $2 h$ periods}

Fig. I. shows the pattern of $2 \mathrm{~h}$ food intakes when both $\mathrm{Zn}$-deficient and control rats were offered the standard diets. Intakes of $0.3 \mathrm{~g}$ or less were found more frequently with the $\mathrm{Zn}$-deficient than with the control rats. However, if only those intakes of greater than $0.3 \mathrm{~g}$ were considered, the distribution of intakes in the two groups of rats was very similar. Even with the $\mathrm{Zn}$-deficient rats, intakes of $0.3 \mathrm{~g}$ or less accounted for less than $5 \%$ of the total food consumed and the rats were therefore considered to have failed to eat a significant amount of food if the intake in $2 \mathrm{~h}$ did not exceed $0.3 \mathrm{~g}$. The reduced food intake in the $\mathrm{Zn}$-deficient group was clearly the result of the failure of the rats to eat food in a large number of $2 \mathrm{~h}$ periods and not the result of a reduction in the amount consumed when the rats did eat. 
(a)

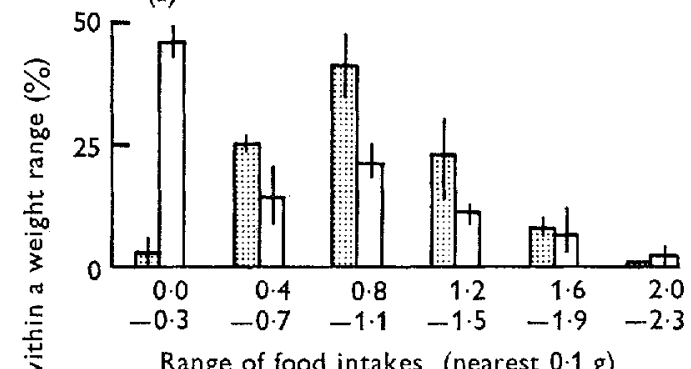

Range of food intakes (nearest $0.1 \mathrm{~g}$ )

0
0
0
0
0
0
0
0
0
0
0
0
0
0

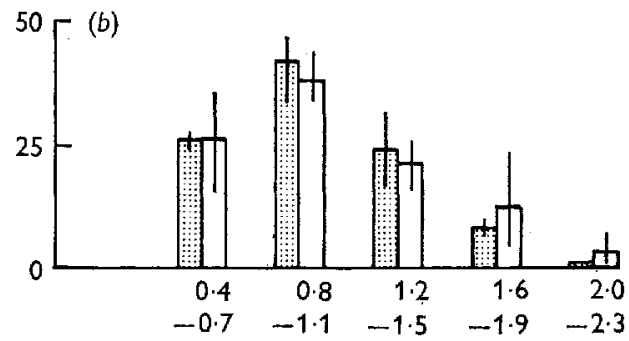

Range of food intakes (nearest $0.1 \mathrm{~g}$ )

Fig. $\mathrm{x}$. Expt 2. Food eaten in $2 \mathrm{~h}$ by $\mathrm{Zn}$-deficient and control male rats. Food intakes in $2 \mathrm{~h}$ were measured to the nearest $0.1 \mathrm{~g}$ and were assigned to one of the six weight ranges shown. The figure shows the average percentage distribution of the numbers of food intakes within the weight ranges for three $\mathrm{Zn}$-deficient and three control rats; the range of values for individual rats is indicated. (a) All food intake values considered; (b) only intakes of greater than $0.3 \mathrm{~g}$ used for the analysis. $\square, \mathrm{Zn}$-deficient; 国, $\mathrm{Zn}$-supplemented.

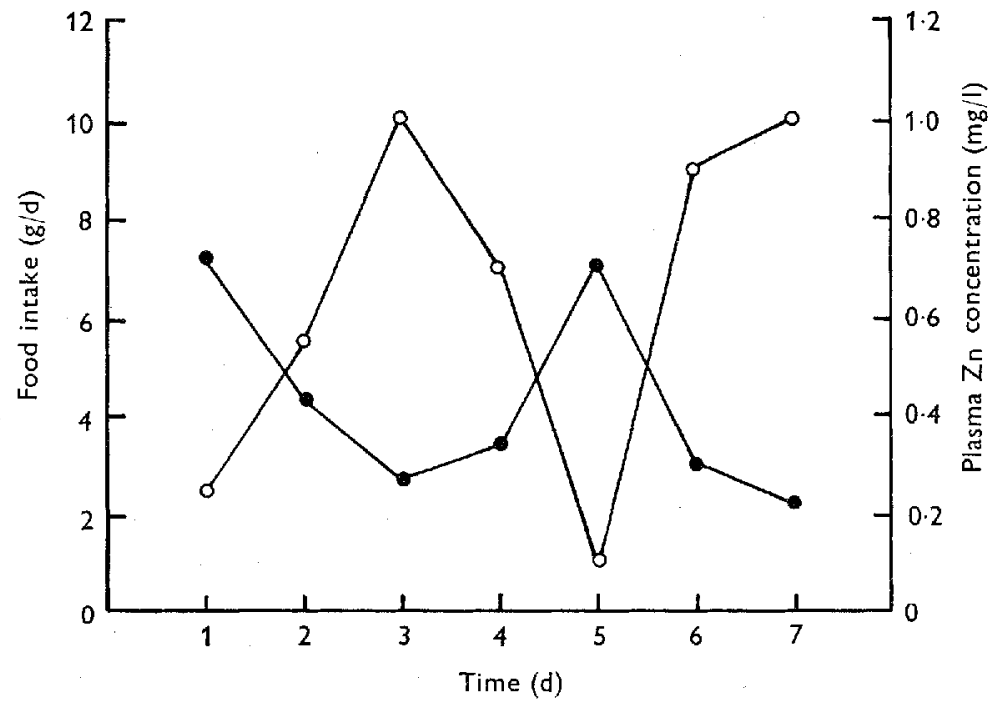

Fig. 2. Expt 3. Relationship between plasma $\mathrm{Zn}$ concentration and food intake. The points represent plasma $\mathrm{Zn}$ concentrations of a $\mathrm{Zn}$-deficient male rat at 09.30 hours on the day indicated and its $a d l i b$. food intake in the previous $24 \mathrm{~h} . \mathrm{O}-\mathrm{O}$, food intake; -1 , plasma Zn concentration. 
Table 7. Expt 3. Relationship between food intake in $24 h$ and plasma zinc concentration at 09.30 hours on preceding and subsequent days for a group of eight $Z n$-deficient male rats

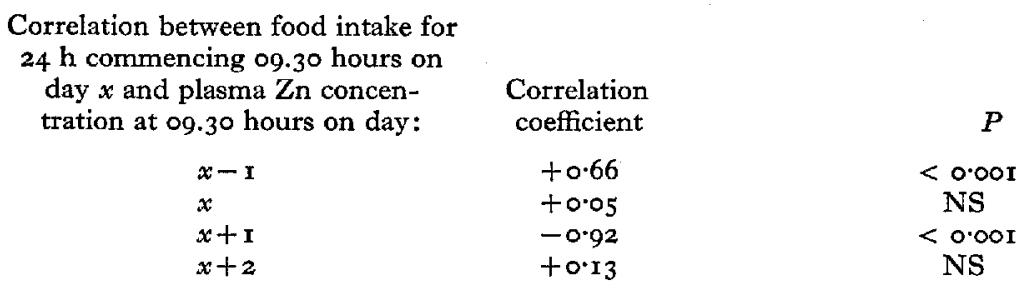

NS, not significant.

\section{Expt 3. Relationship of plasma $Z n$ concentration to} food intake of $Z n$-deficient rats

Fig. 2. shows the relationship between plasma $\mathrm{Zn}$ concentration at 09.30 hours and food intake on successive days for one $\mathrm{Zn}$-deficient rat. Similar results were obtained for eight $\mathbf{Z n}$-deficient rats.

Significant correlations were found to exist between food intake in $24 \mathrm{~h}$ and plasma $\mathrm{Zn}$ concentration both $24 \mathrm{~h}$ before the starts of the periods of food intake and at the ends of the periods (Table 7). However, the closeness of association of the inverse correlation between $24 \mathrm{~h}$ food intake and plasma $\mathrm{Zn}$ concentration at the end of the $24 \mathrm{~h}$ was significantly greater $(P<0.01)$ than that of any of the other correlations tested.

\section{DISCUSSION}

The plasma $\mathrm{Zn}$ concentrations of $\mathrm{Zn}$-deficient rats were found to vary from day to day in a manner similar to the cyclical variation in food intake (Fig. 2) and it might be postulated that availability of $\mathrm{Zn}$ directly controlled the food intake of $\mathrm{Zn}$-deficient rats. However, when the $\mathrm{Zn}$ content of the diet was unchanged, the food intake of the rats could be increased by reducing the metabolizable energy content of the diet or by decreasing the environmental temperature (Table 2). The variability of intake was not significantly affected by the changes in metabolizable energy and temperature but was reduced when the diet offered had a low protein:energy ratio although this diet (LP) had a lower $\mathrm{Zn}$ concentration than the standard $\mathrm{Zn}$-deficient diet. Dietary $\mathrm{Zn}$ content was therefore not the only factor controlling the pattern of food intake of deficient rats. Statistical analysis of the patterns of plasma $\mathrm{Zn}$ concentration and food intake showed that the inverse correlation between food intake during a day and plasma $\mathrm{Zn}$ concentration at the end of the $24 \mathrm{~h}$ was more significant than any of the other correlations tested. Such a correlation does not necessarily suggest a direct causative relationship between food intake and plasma $\mathrm{Zn}$ concentration. Also, plasma $\mathrm{Zn}$ may not be in rapid equilibrium with $\mathrm{Zn}$ at the site or sites of control of food intake. However, fluctuations in plasma $\mathrm{Zn}$ could have resulted from variations in food intake rather than from the reverse of this situation. A possible explanation for this type of relationship is given below.

The reduction in ad lib. food intake of $\mathrm{Zn}$-deficient rats is such that pair-fed 
control rats receiving adequate amounts of $\mathrm{Zn}$ can maintain body-weight but fail to grow (Chesters \& Quarterman, 1970). The mean food intake of a $\mathrm{Zn}$-deficient rat is therefore approximately equivalent to the maintenance requirement of a $\mathrm{Zn}$ adequate rat of the same body-weight. This conclusion was substantiated by calculations based on published estimates of the maintenance energy requirements of rats and the amount by which their voluntary intake exceeds these requirements ((US) National Research Council, I962). Using these estimates and the gross energy content of the standard diet, $\mathrm{I} \cdot 88 \times 10^{7} \mathrm{~J} / \mathrm{kg}(4500 \mathrm{kcal} / \mathrm{kg})$, the likely maintenance intakes of rats weighing 90 and $\mathrm{I}$ ro $\mathrm{g}$ were calculated to be 5.7 and $6.5 \mathrm{~g} / \mathrm{d}$ respectively. These estimates were similar to the experimentally determined mean intakes of 5.6 and $6.8 \mathrm{~g} / \mathrm{d}$ for $\mathrm{Zn}$-deficient rats weighing 90 and $\mathrm{I} I 0 \mathrm{~g}$. When the energy requirements of the $\mathrm{Zn}$-deficient rats were increased by a reduction in the environmental temperature, or when the metabolizable energy content of the diet was reduced, there was a compensatory change in food intake. The accumulated evidence suggests that rats which were unable to grow because of a lack of $\mathrm{Zn}$ reduced their food intake, so that over a period of several days their mean energy intake corresponded with their utilization of energy for maintenance.

Although food intake by the $\mathrm{Zn}$-deficient rats appeared to have been controlled over longer periods by their energy balance, the mechanism of the short-term regulation associated with the cycles of food intake was less clear. Chesters \& Quarterman (1970) showed that when protein concentrations in $\mathrm{Zn}$-deficient diets were low there was no cycling of food intake, and it was postulated that the cycles of food intake of the $\mathrm{Zn}$-deficient rat might be caused by the accumulation of toxic metabolites of protein after days of high food intake. The presence of these metabolites might inhibit food intake until the cortinuing metabolism of the animal resulted in their detoxification. However, these experiments have shown that a two-fold increase in the protein content of the diet did not result in a change either in the food intake of the deficient rats or in the variability of food intake. In addition, cold-exposed rats increased their food intake and therefore their protein intake two-fold without altering the day-to-day variability of intake. It seems unlikely, therefore, that accumulation of protein metabolites specifically affected the food intake of the $\mathrm{Zn}$-deficient rats.

On days of peak intake the quantities of food eaten by $\mathrm{Zn}$-deficient rats were similar to those eaten by control rats offered the $\mathrm{Zn}$-supplemented diet ad lib. As a large proportion of the food intake of the control rats was required for growth, similar intakes by $\mathrm{Zn}$-deficient rats were in excess of maintenance requirements for $24 \mathrm{~h}$. Either this excess of energy intake over maintenance requirement was expended wastefully or it was utilized for the storage of energy reserves. Over a period of $\mathrm{r}_{4} \mathrm{~d}$ the intake of the $\mathrm{Zn}$-deficient rats allowed both these and control rats pair-fed with them to maintain their body-weight. It seems likely that in both groups excess energy assimilated on days of high intake was stored and utilized on succeeding days of submaintenance intake. Days of peak intake would therefore have been associated not with the accumulation of toxic metabolites but with an increase in energy reserves. The normal control of food intake to balance energy utilization has been shown to to be an accurate but relatively slow process (Widdowson, Edholm \& McCance, 
1954; Edholm, Fletcher, Widdowson \& McCance, r955). It seems likely that the increase in energy reserves of the $\mathrm{Zn}$-deficient rats after days of peak intake would have been detected and would have resulted in a reduction of food intake to submaintenance amounts on subsequent days until the energy balance of the rats had been restored. In terms of meal size the $\mathrm{Zn}$-deficient rats appeared to lack any appreciation that the diet was inadequate for growth and once energy reserves of the rat returned to normal, food intake might have been expected to revert to the normal for a $\mathrm{Zn}$-adequate rat of the same body-weight. This would result once more in an excess of energy intake over expenditure and result in resumption of the cycle of intake.

R. B. Williams (personal communication) has shown that the urinary output of nitrogen by $\mathrm{Zn}$-deficient rats is related within $24 \mathrm{~h}$ to the pattern of food consumed, and it seems likely that days of low food intake would therefore correspond to days of low amino acid availability within the animals. This would result in net protein catabolism and a release of some of the $\mathrm{Zn}$ which is normally firmly bound to protein. Once food intake and therefore the supply of dietary amino acids increased, any available $\mathrm{Zn}$ would be reutilized for the synthesis of tissue. These factors would tend to result in an inverse relationship between the availability of $\mathrm{Zn}$ and the pattern of food intake: this type of relationship between plasma $\mathrm{Zn}$ and food intake in the previous $24 \mathrm{~h}$ was demonstrated.

It is postulated that the food intake of $\mathrm{Zn}$-deficient rats in both the long term and short term was regulated by the balance between energy intake and expenditure provided that the protein: energy ratio of the diet would normally have been adequate for growth. However, the low-protein diets failed to support growth even when adequately supplemented with $\mathrm{Zn}$. Under these conditions the daily food intake of the rats might have been expected to decrease to a value only slightly above maintenance and similar to that of deficient rats offered the standard diet, but the intake of control rats offered low-protein diets was significantly greater. It is suggested that, in the absence of an adequate concentration of dietary amino acids, food intake was stimulated by a second regulator. This regulator apparently functioned in maintenance of an adequate amino acid intake and resulted in an imbalance between energy intake and expenditure. This regulation of protein intake seems to have applied equally to both control and $\mathrm{Zn}$-deficient rats since their consumptions of low-protein diets were the same in both magnitude and variability. If these diets were supplemented with the limiting essential amino acids, the importance to the Zn-deficient rats of maintaining these increased intakes would have been expected to diminish and therefore the pattern of food intake would be expected to revert to one similar to that obtained when energy balance was the prime regulator. Such a change in the pattern of food intake was observed when the deficient rats were offered the low-protein diets supplemented with essential amino acids.

We wish to acknowledge the able assistance of Miss $\mathrm{N}$. Hunter and the many helpfuI discussions of this work with our colleagues. We also wish to thank $\mathrm{Mr} \mathrm{A}$. W. Boyne for statistical analysis of the plasma $\mathrm{Zn}$ results and $\mathrm{Dr}$ W. A. Dewar for providing amino acid analyses of the egg albumen. 


\section{REFERENCES}

Chesters, J. K. \& Quarterman, J. (1970). Br. F. Nutr. 24, 106r.

Edholm, O. G., Fletcher, J. G., Widdowson, E. M. \& McCance, R. A. (1955). Br. F. Nutr. 9, 286.

Griffith, P. R. \& Alexander, J. C. (1972). Nutr. Rep. Int. 6, 9.

Hotelling, H. (1 940). Ann. Math. Statist. Ix, 27 I.

Hsu, J. M. \& Anthony, W. L. (197x). F. Nutr. ror, 445.

National Research Council (1962). Publs natn. Res. Coun., Wash. no. 990.

Pallauf, J. \& Kirchgessner, M. (197 I). Z. Tierphysiol. Tierernähr. Futtermittelk. $28,128$.

Quarterman, J., Williams, R. B. \& Humphries, W. R. (1970). Br. F. Nutr. 24, ro49.

Widdowson, E. M., Edholm, O. G. \& McCance, R. A. (1954). Br. F. Nutr. 8, 147.

Williams, R. B. \& Mills, C. F. (1970). Br. 7. Nutr. 24, 989. 